\title{
7 se EXPERIMENTAL STUDY ON PARAMETERS OPTIMIZATION IN CNC PLASMA ARC CUTTING (AISI 206 STEEL) USING TAGUCHI APPROACH
}

Surender Kumar

E-Mail Id: surender10161007@gmail.com

PhD Research Scholar, Department of Mechanical Engineering, NIT, Jalandhar (PB), India

Abstract- Today CNC plasma arc machines are used to cut metal plates in industry. This technique use propane $\left(\mathrm{C}_{2} \mathrm{H}_{2}\right)$ and oxygen $\left(\mathrm{O}_{2}\right)$ gases for heating steel plats $\left(760^{\circ} \mathrm{C}\right.$ to $\left.871^{\circ} \mathrm{C}\right)$, and it is able to cut metal plates at specific areas. Only straight path of the oxygen jet is affected during metal cutting process. This machine has high accuracy level, high finishing, and ability of machining any hard materials. Thus to produce intricate shape increases its demand in the market. Taguchi and Analysis of Variances (ANOVA) approach were used in CNC flame cutting process parameters optimization for AISI 206 steel. Taguchi and Analysis of Variances (ANOVA) approach are used in CNC flame cutting process parameters optimization for AISI 206 steel. The present research paper deals with the optimization of selected process parameters such as kerf and penetration by using inputs as Nozzle speed, Gas pressure, and Plate thickness. The experiments are conducted by using Taguchi $\mathrm{L}_{9}$ orthogonal array method and analysis was done by Minitab 17 software. Taguchi method, Signal to Noise (S/N) ratio between the input parameters and output responses are also predicted in this paper. Optimization results have been determined with the help of main effect plot and ANOVA table. ANOVA results presented that the pressure of gases and speed of nozzle are significant parameters for minimizing Kerf as well as for maximizing Penetration.

Keywords- AISI 206 steel, Kerf \& Penetration optimization, ANOVA \& Taguchi analysis, Machinability

\section{INTRODUCTION}

Thermal manufacturing and non-conventional machining method used for processing different electrical conducting materials (i.e. carbon steel, stainless-steel, aluminium, cast iron and non-ferrous metals), is known as Plasma Arc Cutting (PAC). PAC working process and mechanism is shown in figure 1.1. PAC can be used for the cutting of metal plates whose thickness lies between $(5-40 \mathrm{~mm})$. CNC plasma arc cutting machine is used to perform experimental work in this study. In this machine, preheating oxygen $\left(\mathrm{O}_{2}\right)$ and fuel gas $\left(\mathrm{C}_{2} \mathrm{H}_{2}\right)$ are used for cutting steel plates. In this process have electrode (as cathode) and workpiece material (as anode). Plasma arc grants high temperature which is used to cut the metal by melting process, which removes away the molten metal efficiently through gas pressure. In this research paper, the multi-parameter optimization of the PAC process (kerf and penetration characteristics) has been experimentally studied. All parameter optimization was conceded out, by using the full factorial DOE method. The feasibility and effectiveness of all parameter optimization is experimentally proving by using Taguchi Method [1-8]. This process is used in many industries (metal fabrication, automotive repair, construction, metal salvage, metal art and sculpting.

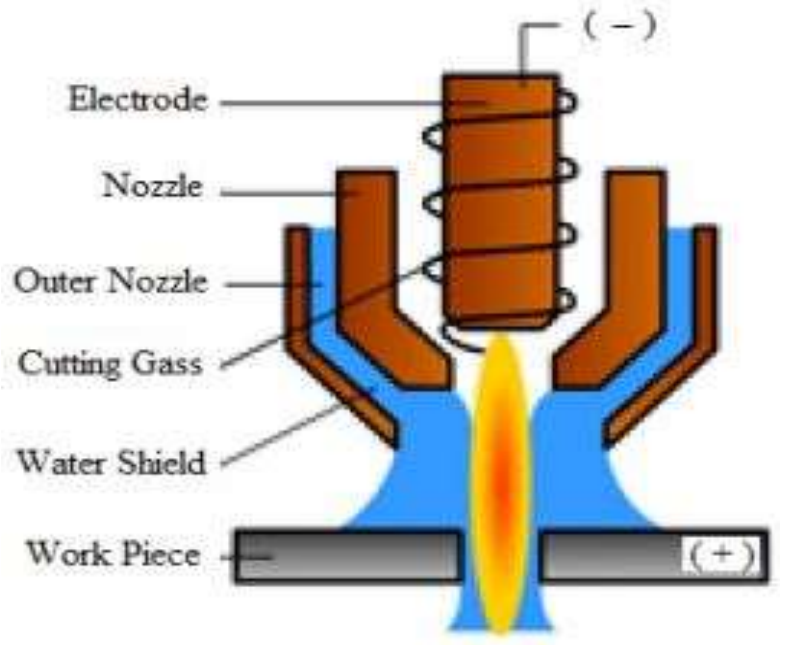

(a)

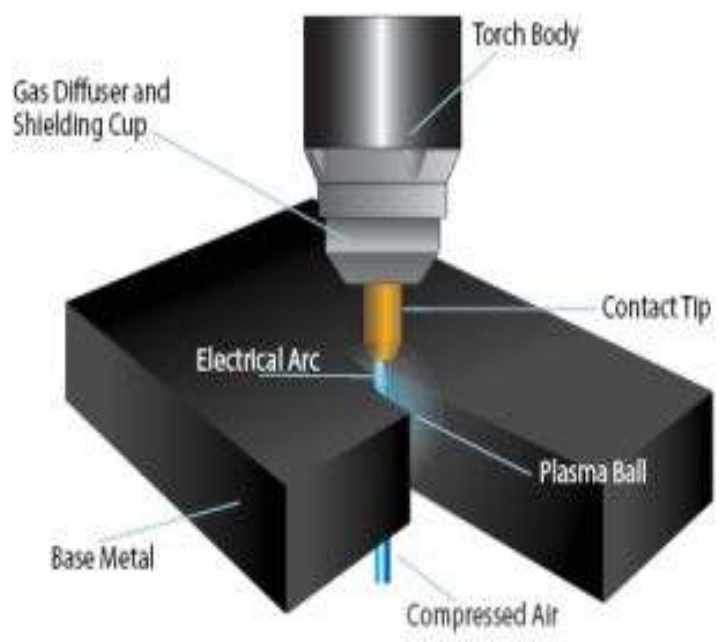

(b)

DOI Number: 10.30780/IJTRS.V3.I6.2018.003

pg. 198

Www.ijtrs.com

WWW.ijtrs.org 


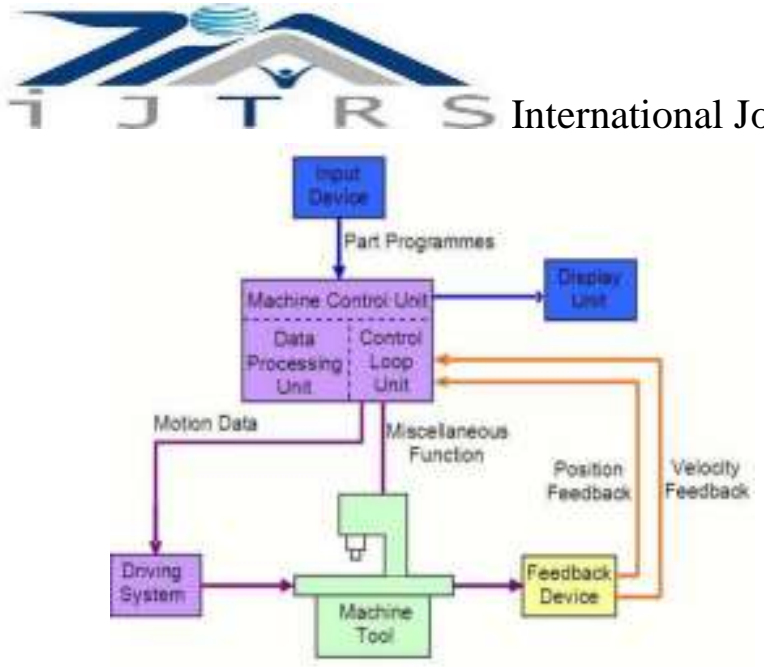

(c)

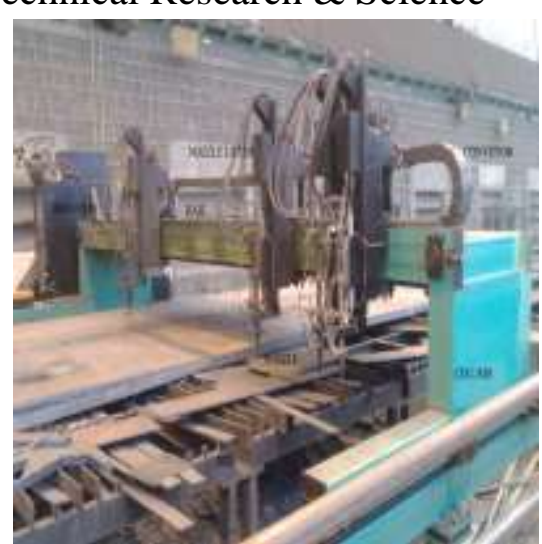

(d)

Fig. 1.1 CNC Plasma Arc Cutting Principle [5]

\section{STEPS USE IN TAGUCHI METHODOLOGY}

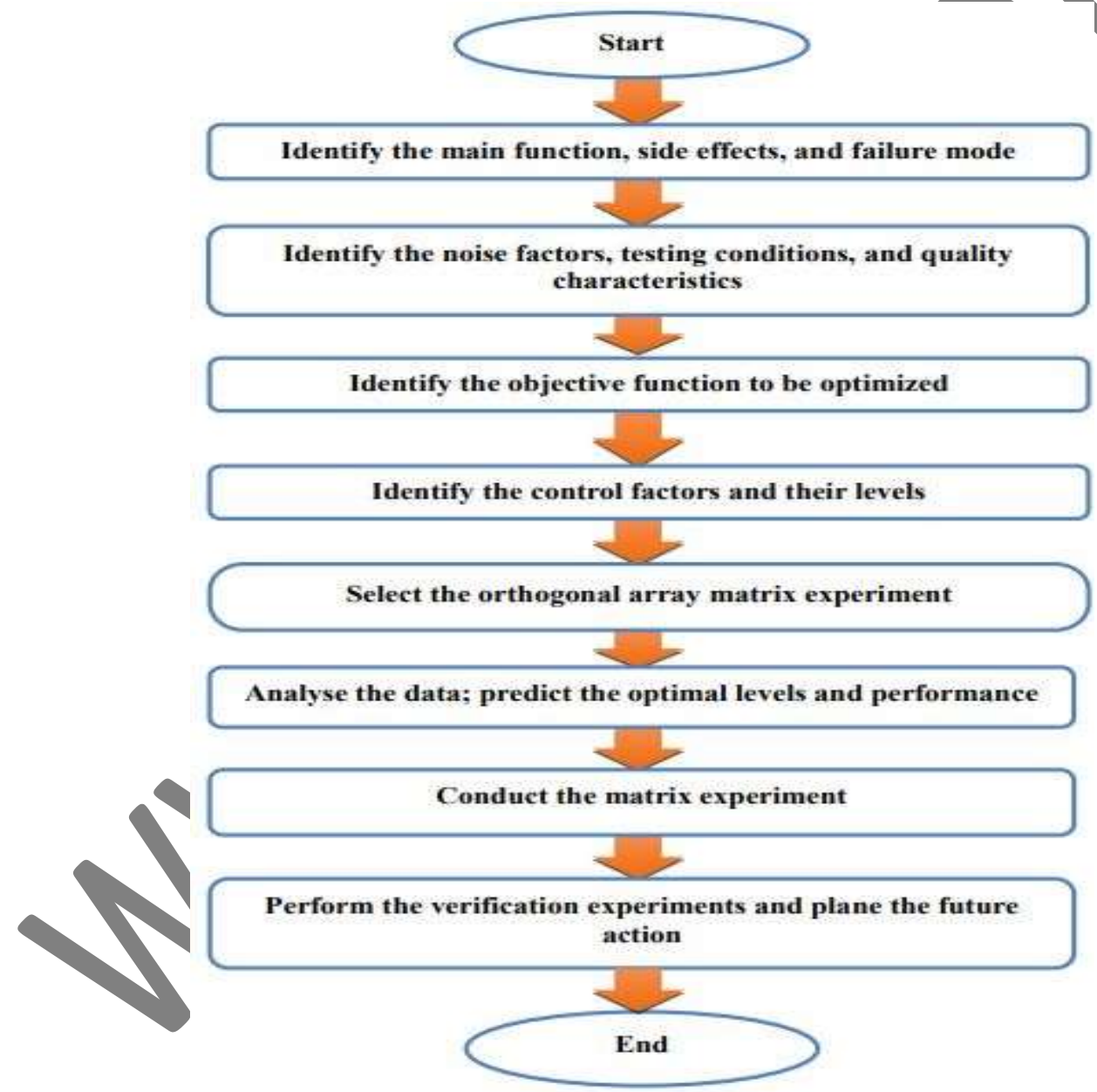

Fig. 2.1 Flow Chart for Taguchi Methodology

Taguchi method was developed by Dr. Genichi Taguchi born in 1924 in Japan. This is a Fractional Factorial design method based on orthogonal array. This method also requires a large number of experiments when the process parameters increase. This technique is used to find best set of values of controllable factors to type the design less sensitive with variation of noise, which means that Taguchi make a design more robust. Main performance measuring character of Taguchi is signal-to-Noise ratio or simply known as $\mathrm{S} / \mathrm{N}$ ratio [9-15]. There are three different cases for $\mathrm{S} / \mathrm{N}$ ratio:

\subsection{Smaller is Better}

It is used to minimize the response, means where output is undesirable.

DOI Number: 10.30780/IJTRS.V3.I6.2018.003

pg. 199

Www.ijtrs.com

www.ijtrs.org 


\subsection{Larger is Better}

International Journal of Technical Research \& Science

$$
S N R=-10 \log _{10}\left[\frac{\sum Y_{i}^{2}}{n}\right]
$$

This is used to maximize the response, means where output is desirable. This case can be converted is Smaller-isBetter when we take reciprocal of all measured data and calculate the $\mathrm{S} / \mathrm{N}$ ratio as Smaller-is Better.

\subsection{Nominal is Better}

$$
S N R=-10 \log _{10}\left[\frac{\Sigma \frac{1}{Y_{i}^{2}}}{n}\right]
$$

This type is used when neither a lesser and nor a higher value is required for response.

$$
S N R=-10 \log _{10}\left[\frac{\sum \bar{Y}^{2}}{\sigma^{2}}\right]
$$

$Y$ - Measured output data of experiment, $Y_{i}$ - Measured output data of $\mathrm{i}^{\text {th }}$ experiment, $\bar{y}$ - Mean of measured output data of experiments, $\sigma^{2}-$ Variance, $\sigma$ - Standard deviation

Number of experiments used to design the orthogonal array for 3 parameters and 3 levels of CNC plasma are cutting machine parameters.

\subsection{ANOVA}

$$
\text { Minimum experiments }=[(\mathrm{L}-1) \times p]+1=[(3-1) \times 3]+1 \approx L 9
$$

This is used to check whether means of more than two set quantities are equal or not with the help of F-test. It is a statistical tool applied on result of Taguchi experiment to determine percentage contribution of factors. It use S/N ratio of Taguchi method for this calculation [16-20].

\section{STEPS USE IN TAGUCHI METHODOLOGY}

For the experiments, Mild steel (carbon steel) - IS206 A grade, which is universally use for industrial applications, was used. Gas pressure used during CNC plasma are cutting experiment in oxygen bottle $\left(150 \mathrm{~kg} / \mathrm{cm}^{2}\right)$ and acetylene bottle $\left(20 \mathrm{~kg} / \mathrm{cm}^{2}\right)$. Electrical arc formed turns some part of the gas into plasma which starts removing material in form of small kerfs by melting sheet material. All experiments were conducted on a CNC plasma cutting machine with a double gas flow torch. The specimens were prepared by linear cuts on metal sheet as shown in figure 3.1. The cutting materials were permitted to cool at room temperature. Each experiment was performed two times and all measurements were taken along the cut in the straight line portion. In the present study, the major performance characteristics considered are Kerf and penetration. The cutting parameters such as speed, pressure and thickness were analyzed and optimized with consideration of workpiece Kerf and penetration.
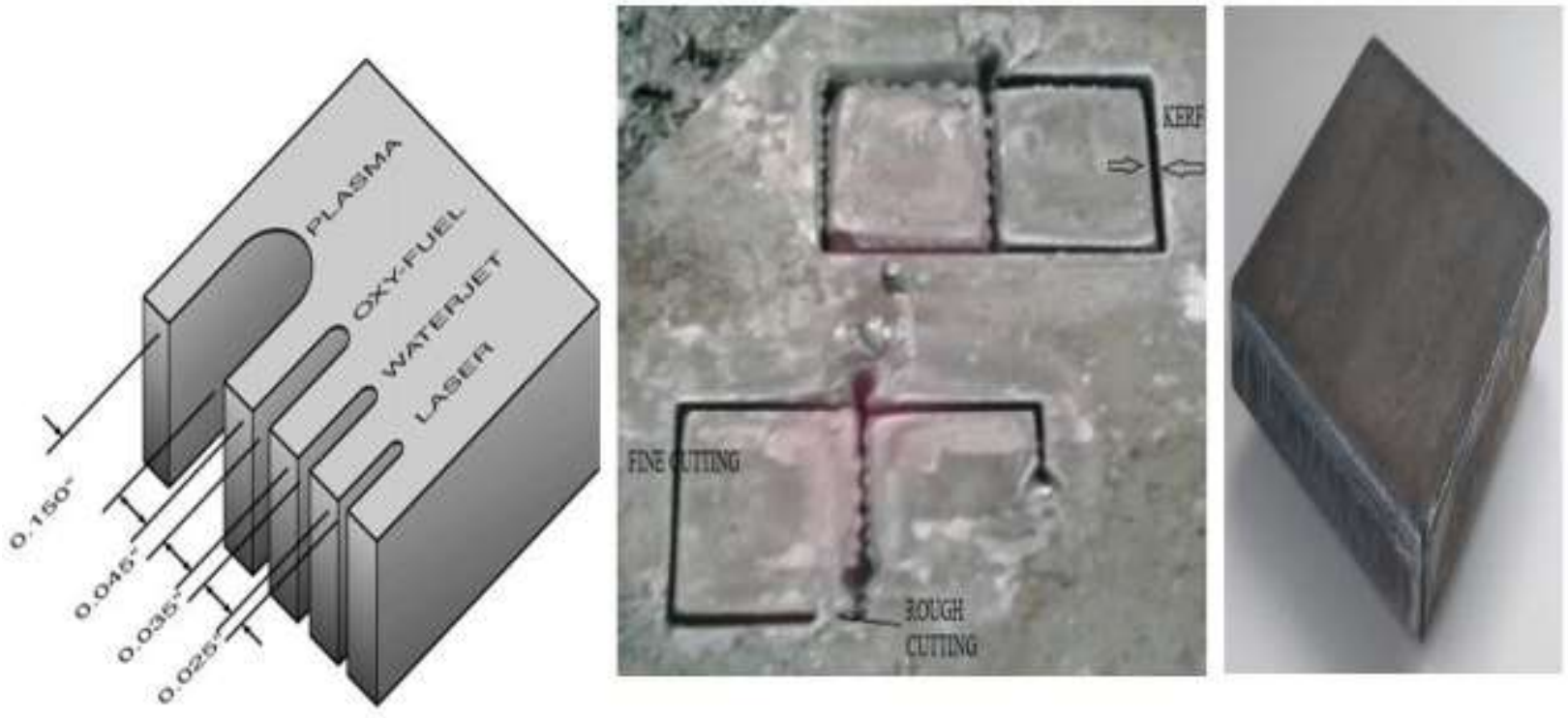

Fig. 3.1 CNC Plasma Cutting Workpiece With Kerf

\section{EFFECT OF CUTTING PARAMETERS ON CUT QUALITY}

During CNC plasma arc cutting process, operation quality of cut which depends on three main parameters such as cutting speed, oxygen pressure in touch and type of nozzle used [20-24].

DOI Number: 10.30780/IJTRS.V3.I6.2018.003

pg. 200

www.ijtrs.com

www.ijtrs.org 


\subsection{Cutting Speed}

The rise in cutting speed decreases the quality of the cut resulting in rounding of the bottom edge to some extent and also undercuts the edge which destroys the flatness. Slow speed results in unstable operation which causes gauges in the face of the cut.

\subsection{Oxygen Pressure in Touch}

When oxygen pressure rise, Diameter of the stream increases which increases the width of cut and provides less oxygen to oxidize the steel which results in loss of quality. Also when oxygen pressure is less the gauging takes place and slag will not be removed from the surface of the metal.

\subsection{Nozzle}

When excessed oxygen pass through the cut of plate, which result in the bottom of the cut being wider than the top. Increase in speed can reduce the cut width and face angle but at the cost of quality of surface. Smaller nozzles can be used to cut heavier thickness with dramatic reductions in speed with comparatively good quality.

\section{RESULTS AND DISCUSSIONS}

Results from all experiments by using Taguchi and ANOVA methods are showing in table 1 . The experiments were designed and conducted by employing Taguchi and ANOVAs method. The selection of appropriate model and the development of response were carried out by using statistical. The analysis of variance (ANOVA) was performed to statistically analyze the results. To decide about the adequacy of the model, F Test and ANOVAs method were performed.

Table 5.1 Experimental results using Taguchi and ANOVA methods

\begin{tabular}{|c|c|c|c|c|c|c|c|c|c|}
\hline \multirow{2}{*}{$\begin{array}{l}\text { Exp. } \\
\text { No. }\end{array}$} & \multicolumn{3}{|c|}{ Factor assignment } & \multirow{2}{*}{$\begin{array}{l}\text { Kerf } \\
(\mathrm{mm})\end{array}$} & \multirow{2}{*}{$\begin{array}{c}\text { S/N ratio } \\
(\mathrm{db})\end{array}$} & \multirow{2}{*}{$\begin{array}{l}\text { Mean } \\
(\mathrm{mm})\end{array}$} & \multirow{2}{*}{$\begin{array}{l}\text { etration } \\
(\mathrm{mm})\end{array}$} & \multirow{2}{*}{$\begin{array}{c}\text { S/N ratio } \\
\text { (db) }\end{array}$} & \multirow{2}{*}{$\begin{array}{l}\text { Mean } \\
(\mathrm{mm})\end{array}$} \\
\hline & $\begin{array}{c}\text { Speed } \\
(\mathrm{mm} / \mathrm{min})\end{array}$ & $\begin{array}{c}\text { Pressure } \\
\text { (Bar) }\end{array}$ & $\begin{array}{c}\text { Plate } \\
\text { thickness } \\
(\mathrm{mm})\end{array}$ & & & & & & \\
\hline 1 & 380 & 0.12 & 15 & & & 2.7 & 22 & 26.8485 & 22 \\
\hline 2 & 380 & 0.30 & 25 & & & 1.9 & 28 & 28.9432 & 28 \\
\hline 3 & 380 & 0.45 & 50 & & 1.58362 & 1.2 & 51 & 34.1514 & 51 \\
\hline 4 & 460 & 0.12 & 25 & & -6.84845 & 2.2 & 18 & 25.1055 & 18 \\
\hline 5 & 460 & 0.30 & 50 & 1.7 & -4.60898 & 1.7 & 23 & 27.2346 & 23 \\
\hline 6 & 460 & 0.45 & & 1.0 & 0.0000 & 1.0 & 43 & 32.6694 & 43 \\
\hline 7 & 540 & 0.12 & & 1.9 & -5.57507 & 1.9 & 14 & 22.9226 & 14 \\
\hline 8 & 540 & & & 1.3 & -2.27887 & 1.3 & 20 & 26.0206 & 20 \\
\hline 9 & 540 & & 25 & 0.7 & 3.09804 & 0.7 & 40 & 32.0412 & 40 \\
\hline
\end{tabular}

5.1 Taguchi Analysis: Kerf (Smaller is Better) Versus Speed, Pressure, Thickness

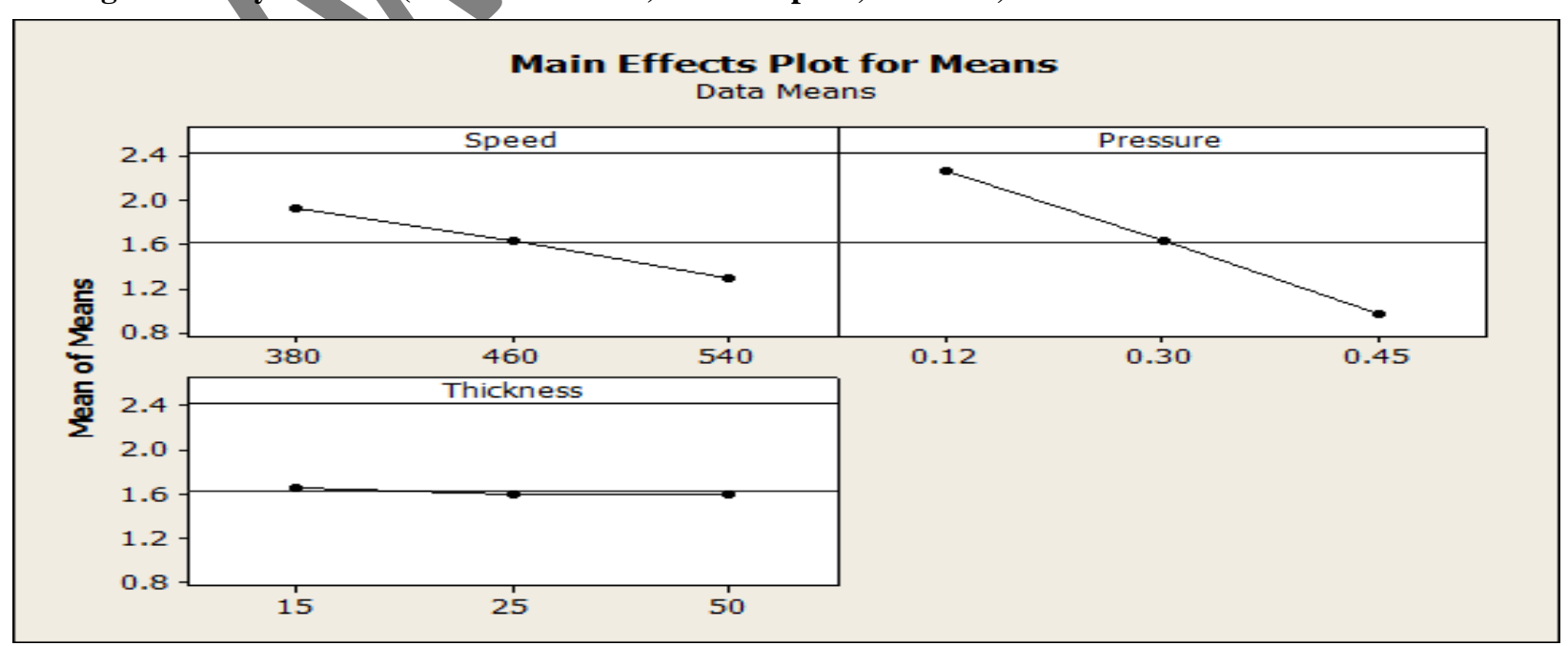

Fig. 5.1 Factors Vs Mean of Means

DOI Number: 10.30780/IJTRS.V3.I6.2018.003

www.ijtrs.com

www.ijtrs.org

pg. 201

Paper Id: IJTRS-V3-I6-003 
I T R S International Journal of Technical Research \& Science

Table 5.2 Response Table for Means

\begin{tabular}{|c|c|c|c|}
\hline Level & Speed & Pressure & Thickness \\
\hline 1 & 1.9333 & 2.2667 & 1.6667 \\
\hline 2 & 1.6333 & 1.6333 & 1.6000 \\
\hline 3 & 1.3000 & 0.9667 & 1.6000 \\
\hline Delta & 0.6333 & 1.3000 & 0.0667 \\
\hline Rank & 2 & 1 & 3 \\
\hline
\end{tabular}

Table 5.3 Response Table for S/N Ratio

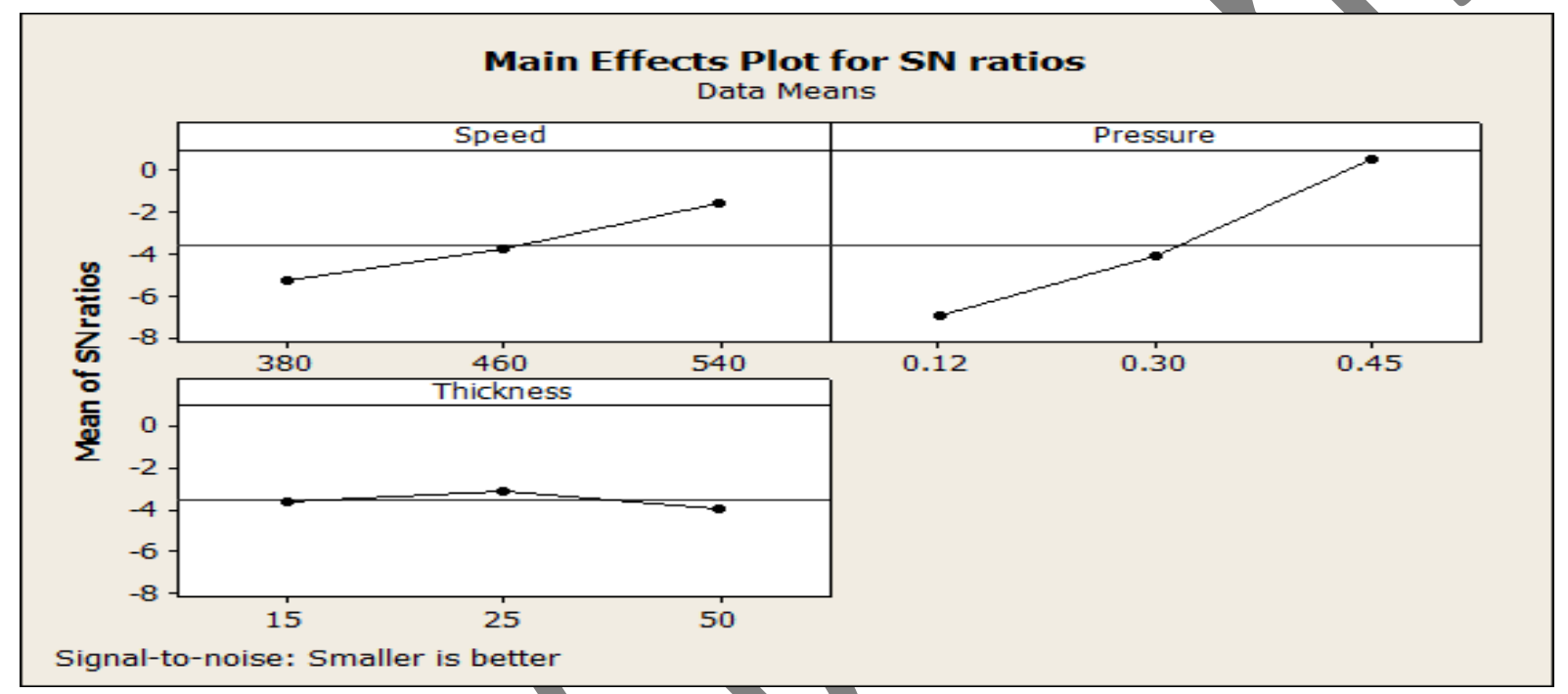

Fig. 5.2 Factors Vs Mean of S/N Ratio

Table 5.4 Gernal Liner Model - Kerf Vs Speed, Pressure, Thickness

\begin{tabular}{|c|c|c|c|c|c|}
\hline Source & DF & Adj. SS & Variance & F-Value & \% \\
\hline Speed & 2 & 0.602 & 0.301 & 20.85 & 19.07 \\
\hline Pressure & 2 & 2.535 & 1.267 & 87.77 & 79.87 \\
\hline Thickness & 2 & 0.008 & 0.004 & 0.31 & 0.41 \\
\hline Error & 2 & 0.028 & 0.014 & 0.63 & \\
\hline Total & 8 & 3.175 & & & \\
\hline
\end{tabular}

5.2 Taguchi Analysis: Penetration (larger is better) versus Speed, Pressure, Thickness

Table 5.5 Response Table for Means

\begin{tabular}{|c|c|c|c|}
\hline Level & Speed & Pressure & Thickness \\
\hline 1 & 33.67 & 18.00 & 28.33 \\
\hline 2 & 28.00 & 23.67 & 28.67 \\
\hline 3 & 24.67 & 44.67 & 29.33 \\
\hline Delta & 9.00 & 26.67 & 1.00 \\
\hline Rank & 2 & 1 & 3 \\
\hline
\end{tabular}

DOI Number: 10.30780/IJTRS.V3.I6.2018.003
Table 5.6 Response Table for S/N Ratio

\begin{tabular}{|c|c|c|c|}
\hline Level & Speed & Pressure & Thickness \\
\hline 1 & 29.98 & 24.96 & 28.51 \\
\hline 2 & 28.34 & 27.40 & 28.70 \\
\hline 3 & 26.99 & 32.95 & 28.10 \\
\hline Delta & 2.99 & 8.00 & 0.59 \\
\hline Rank & 2 & 1 & 3 \\
\hline
\end{tabular}

pg. 202

www.ijtrs.com

www.ijtrs.org 
I T $\mathrm{R} S$ International Journal of Technical Research \& Science

\subsubsection{Effect of Factors on Penetration}

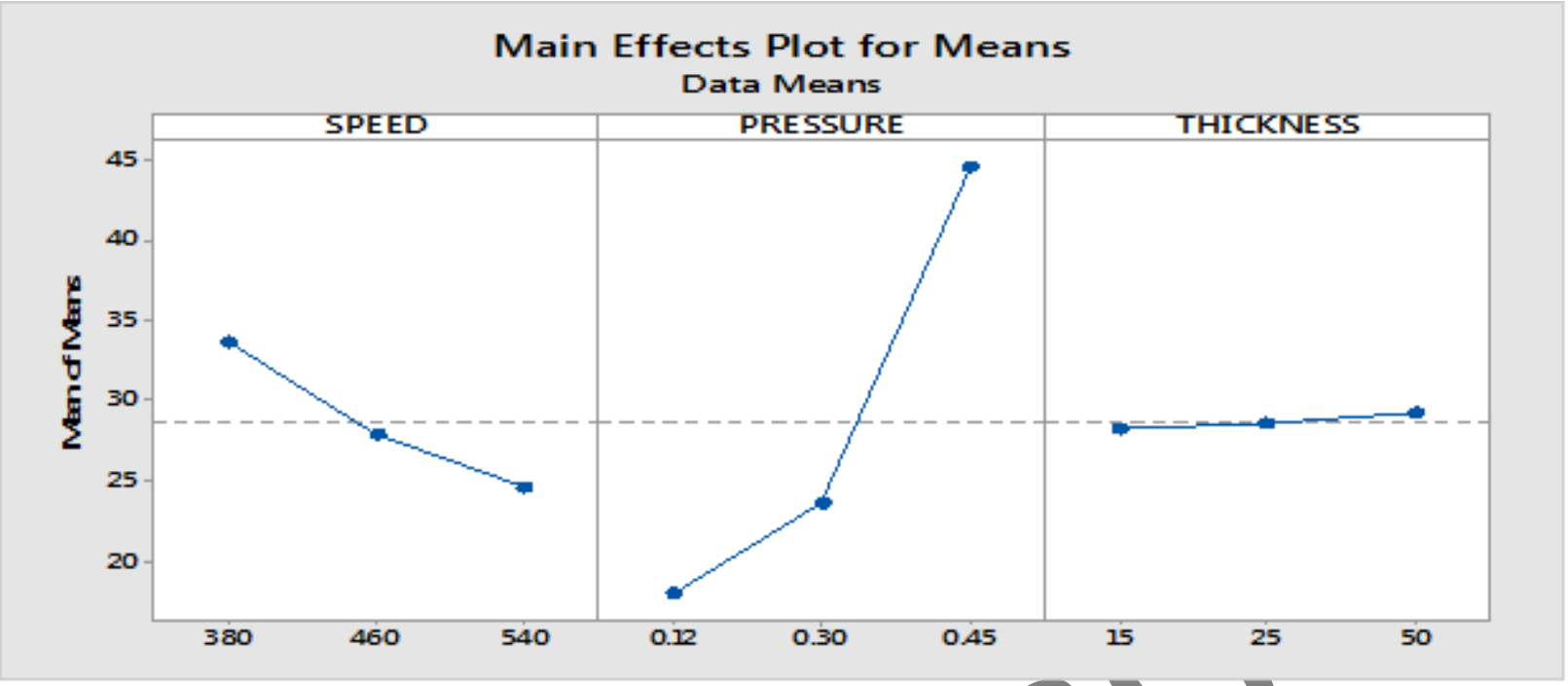

Fig. 5.3 Factors Vs Mean of Means

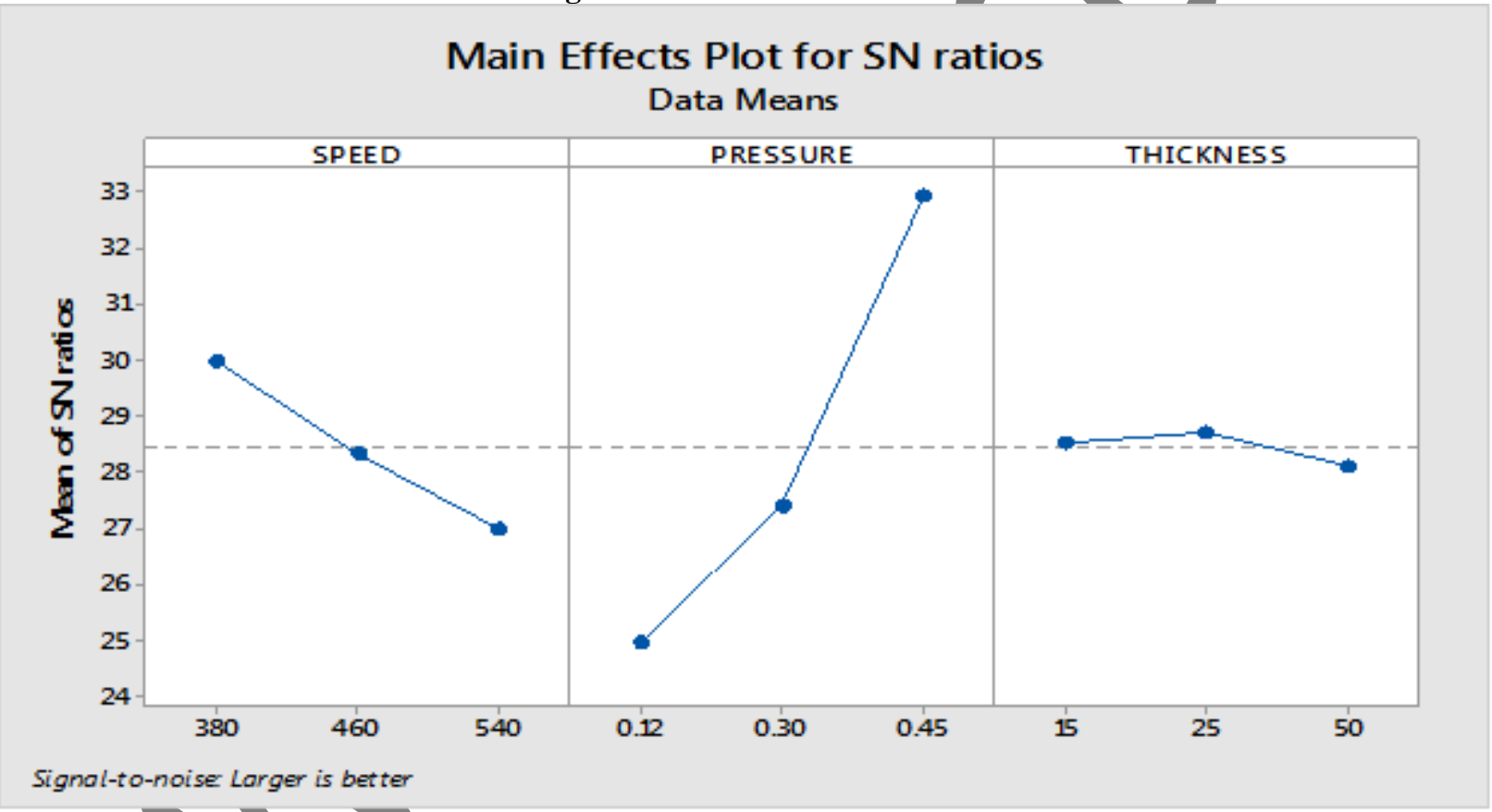

Signal-to-noise Larger is better

Fig. 5.4 Factors $V s$ Mean of S/N Ratio

Table 5.7 Gernal liner model - penetration $V s$ speed, pressure, thickness

\begin{tabular}{|c|c|c|c|c|c|}
\hline Source & DF & Adj. SS & Variance & F-Value & \% \\
\hline Speed & 2 & 124.22 & 62.11 & 34.94 & 9.45 \\
\hline Pressure & 2 & 1184.22 & 592.11 & 333.06 & 90.15 \\
\hline Thickness & 2 & 1.56 & 0.77 & 0.44 & 0.11 \\
\hline Error & 2 & 3.56 & 1.77 & 0.27 & \\
\hline Total & 8 & 1313.56 & & & \\
\hline
\end{tabular}

\section{CONCLUSION}

In this section, the effects of process variables on response characteristics (kerf and penetration) of the CNC flame cutting machining process were discussed. Optimal values of the responses and their confidence intervals (both for confirmation experiment and prediction) are given as under:

DOI Number: 10.30780/IJTRS.V3.I6.2018.003

pg. 203

www.ijtrs.com

www.ijtrs.org 


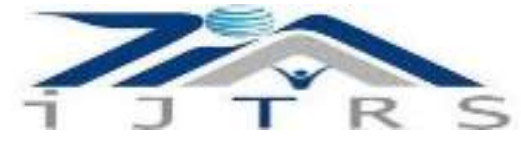

International Journal of Technical Research \& Science

Table-(A) Confirmation test

\begin{tabular}{|c|c|c|c|c|c|c|c|c|}
\hline \multirow{2}{*}{$\begin{array}{c}\text { Performance } \\
\text { measures or } \\
\text { Responses }\end{array}$} & \multicolumn{4}{|c|}{ Mean } & \multicolumn{4}{|c|}{ S/N ratio } \\
\hline & $\begin{array}{c}\text { Optimal set } \\
\text { of } \\
\text { parameters }\end{array}$ & $\begin{array}{c}\text { Predicted } \\
\text { optimal } \\
\text { value }(\mathbf{m m})\end{array}$ & $\begin{array}{l}\text { Exp. } \\
\text { value } \\
(\mathrm{mm})\end{array}$ & $\begin{array}{c}\text { Error } \\
(\%)\end{array}$ & $\begin{array}{c}\text { Optimal } \\
\text { set of } \\
\text { parameter }\end{array}$ & $\begin{array}{c}\text { Predicted } \\
\text { optimal } \\
\text { value } \\
(\mathbf{m m})\end{array}$ & $\begin{array}{l}\text { Exp. } \\
\text { value } \\
(\mathbf{m m})\end{array}$ & $\begin{array}{c}\text { Error } \\
(\%)\end{array}$ \\
\hline Kerf & $\mathrm{A}_{3}, \mathrm{~B}_{3}, \mathrm{C}_{2}$ & 0.62 & 0.70 & 11.11 & $\mathrm{~A}_{1}, \mathrm{~B}_{1}, \mathrm{C}_{3}$ & -9.09 & -8.43 & 7.81 \\
\hline Penetration & $\mathrm{A}_{1}, \mathrm{~B}_{3}, \mathrm{C}_{3}$ & 50.11 & 51 & 2.0 & $\mathrm{~A}_{1}, \mathrm{~B}_{3}, \mathrm{C}_{2}$ & 34.75 & 37.42 & 7.12 \\
\hline
\end{tabular}

The important results from optimal set of process variables in CNC flame cutting machine are written as:

$>$ ANOVA result shows that pressure of gases and speed of nozzle are significant parameters for minimizing Kerf and maximizing Penetration.

$>$ Kerf $(11.11 \%)$ and penetration $(2.0 \%)$ error in mean analysis were obtained, by confirmation experiments.

$>$ Confirmation experiments present that Kerf $(7.81 \%)$ and penetration $(7.12 \%)$ error in s/n ratio were achieved.

$>$ In kerf case optimum sets of parameter for mean analysis was $A_{3} B_{3} C_{2}$ and for $s / n$ ratio was $A_{1} B_{3} C_{3}$ respectively.

$>$ In penetration case optimum sets of parameter for $S / N$ ratio was $A_{1} B_{1} C_{3}$ and for s/n ratio was $A_{1} B_{3} C_{2}$ respectively.

\section{REFERENCES}

[1] Kechagias, J., Billis, M., and Maropoulos, S., “A parameter design of CNC plasma-arc cutting process using robust design”, Int. J. Experimental Design and Process Optimisation, Vol. 1, No. 4, pp. 315-326, 2010.

[2] Bini, R., Colosimo, B.M., Kutlu, A.E., and Monno, M., "Experimental study of the features of the kerf generated by a 200A high tolerance plasma arc cutting system”, Journal of Materials Processing Technology, Vol.196, pp.345-355, 2008.

[3] Asiabanpour, B., Vejandla, D.T., Jimenez, J., and Novoa, C., "Optimising the automated plasma cutting process by design of experiments", Int. J. Rapid Manufacturing, Vol.1, No. 1, pp.19-40, 2009.

[4] Zhou, Q., Li, H., Liu, F., Guo, S., Guo, W., and Xu, P., "Effects of nozzle length and process parameters on highly constricted oxygen plasma cutting are", Plasma Chemistry \& Plasma Processing, Vol. 28, pp.729-747, 2008.

[5] Gullu, A., and Atici, U., "Investigation of the effects of plasma arc parameters on the structure variation of AISI 304 and St 52 steels", Materials \& Design, Vol. 27, pp.1157-1162, 2006.

[6] Chen, J.C., Li, Y., and Cox, R.I., "Taguchi-based Six Sigma approach to optimize plasma cutting process: an industrial case study", International Journal of Advanced Manufacturing Technology, Vol. 41, pp.760-769, 2009.

[7] Gariboldi, E., and Previtali, B., "High tolerance plasma arc cutting of commercially pure titanium", Journal of Materials Processing Technology, Vol. 160, pp.77-89, 2005.

[8] Tsiolikas, A., Kechagias, J., Salonitis, K., and Mastorakis, N., "Optimization of cut surface quality during CNC plasma arc cutting process”, Int. J. of Systems Applications, Engineering \& Development, Vol 10, pp. 305-308, 2016.

[9] Ilii, S.M., Coteata, M., and Munteanu, A., "Experimental results concerning the variation of surface roughness parameter (Ra) at plasma arc cutting of a stainless steel workpiece”, International Journal of Modern Manufacturing Technologies, Vol. 2, No. 1, pp. 31-36, 2010.

[10] Colombo, V., Concetti, A., Dallavalle, S., Fazziioli, R., Ghedini, E., and Vancini, M., "Optimization of plasma arc cutting of mild steel thin plates ”, Journal of High Temperature Material Processes, Vol. 13, No. 3 , pp. 267 285, 2009.

[11] Bahram, A., "Optimising the Automated Plasma Cutting Process by Design of Experiments", International Journal of Rapid Manufacturing, pp. 19-40, 2009.

[12] Ozek, C., Caydas, U., and Unal, E., "A fuzzy model for predicting surface roughness in plasma arc cutting of AISI 4140 Steel”, Materials and Manufacturing Processes, Vol. 2, No. 7, pp. 95-102, 2012.

[13] Huang, J.T., and Lin, J.L., "Optimization of machining parameters setting of die - sinking EDM process based on the grey relational analysis with L18 orthogonal array", J. Technol, Vol. 1, No. 7, pp. 659-664, 2002.

[14] Ramakrishnan, S., Gershenzon, M., Polivka, F., Kearney, T.N., and Rogozinski, M.W., "plasma generation for the plasma cutting process”, IEEE Transactions on Plasma Science, Vol. 25, No. 5, pp. 937-946, 1997. 


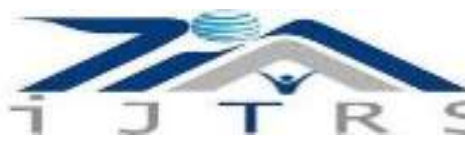

\section{International Journal of Technical Research \& Science}

[15] Hsaio, Y.F., Tarng, Y.S., and Huang, Y.J., "Optimization of plasma arc welding parameters by using taguchi method with grey relational analysis", Mater Manuf. Process, pp. 51-58, 2010.

[16] Lin, C.L, "Use of the Taguchi method and Grey relational analysis to optimize turning operation with multiple performance characteristics", Mater Manuf. Process, pp. 209-220, 2004.

[17] Verma, J., Agrawal, P., and Bajpai, L., "Turning parameter optimization for surface roughness of ASTM A242 Type-1 alloys steel by Taguchi Method", International Journal of Advances in Engineering and Technology, Vol. 3, No. 1, pp. 255-261, 2012.

[18] Rao, S., Ramji, K., and Satyanarayana, B., "Prediction of material removal rate of Aluminum BIS-24345 alloy", International Journal of Engineering Science and Technology, Vol. 2, No. 12, pp. 7729-7739, 2010.

[19] Kaladhar, M., Subbaiah, K.V., and Rao, C.S., "Determination of optimum process parameters during turning of AISI 304 Austenitic Stainless steels using Taguchi method and ANOVA”, International Journal of Lean and Thinking, Vol. 3, No. 1, pp. 1-19, 2012.

[20] Maiyar, L.M., Ramanujam, R., Venkatesan, K., and Jerald, J., “Optimization of machining parameters for end milling of Inconel 718 super alloy using Taguchi based grey relational analysis”, Procedia Engineering, Vol. 6, No. 4, pp. 1276-1282, 2013.

[21] Patel, D.H., and Patni, V.N., “An Investigation Effect of machining parameters on CNC router" International Journal of Engineering Development and Research, Vol. 2, No. 2, pp. 1583-1587, 2014.

[22] Thepsonthi, T., and Ozel, T., "Multi-objective process optimization for micro-end milling of Ti-6Al-4V titanium alloy”, Int J Adv Manuf Technol, Vol. 6, No. 3, pp. 903-914, 2012.

[23] Tsiolikas, A., Kechagias, J., and Salonitis, K., "Optimization of cut surface quality during CNC plasma arc cutting process", International Journal of Systems Applications, Engineering \& Development, Vol. 10, pp. 305308, 2016.

[24] Teja, S.S., Karthik, G., Sampath, S., and Shai, M., "Experimental Investigations to Study the Impact of Machining Parameters on Mild Steel Using Plasma Arc Cutting”, Int. Journal of Engineering Research and Applications, Vol. 5, No. 8, pp. 83-88, 2015. 